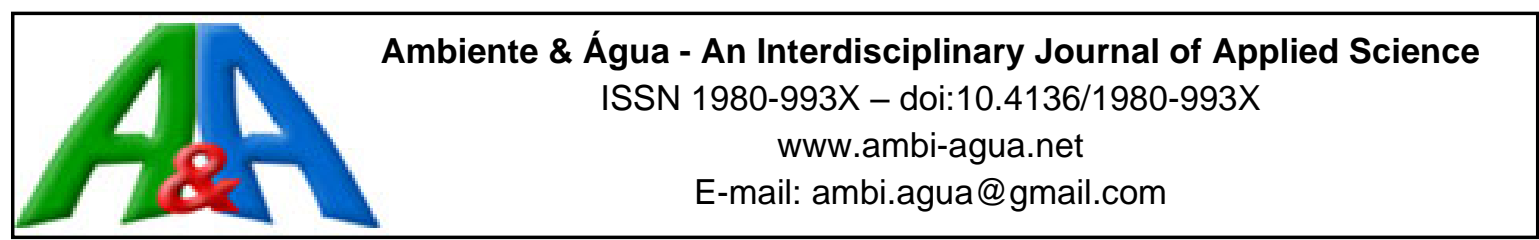

\title{
Freshwater mollusks as proxies for assessing agrochemicals hazards in Volta Grande Reservoir, Brazil
}

\author{
ARTICLES doi:10.4136/ambi-agua.2681
}

Received: 26 Nov. 2020; Accepted: 12 Apr. 2021

\author{
Andressa Mendes Sene ${ }^{1 *(D)}$; Daniel Melo Rosa ${ }^{2,3}$ (D); \\ Silvia Maria Millan Gutierre ${ }^{1}$; Paulo Santos Pompeu ${ }^{1}$
}

${ }^{1}$ Instituto de Ciências Naturais. Departamento de Ecologia e Conservação. Universidade Federal de Lavras (UFLA), Avenida Doutor Sílvio Menicucci, s/n, CEP: 37200-900, Lavras, MG, Brazil.

E-mail: sil.m.gutierre@gmail.com,pompeu@ufla.br

${ }^{2}$ Programa de Pós-graduação em Ciências (FIMAT). Departamento de Física. Universidade Federal de Ouro Preto (UFOP), Rua Cinco, n² 2, CEP: 35400-000, Ouro Preto, MG, Brazil. E-mail: danielnativa@gmail.com

${ }^{3}$ Centro de Bioengenharia de Espécies Invasoras de Hidrelétricas (CBEIH), Avenida José Cândido da Silveira, n² 21000, CEP: 31035-536, Belo Horizonte, MG, Brazil. E-mail: danielnativa@ gmail.com

*Corresponding author. E-mail: andressasene@ hotmail.com

\begin{abstract}
Brazil has experienced a rise in the use of agrochemicals in recent years, representing a potential threat to nearby ecosystems. The Volta Grande Reservoir (Minas Gerais/São Paulo, Brazil) has about $87 \%$ of its area surrounded by agricultural systems, and many compounds used in agriculture end up being carried into nearby water bodies. Given the potential ecological risk, our purpose was to assess pesticides in the reservoir. We collected specimens of two bivalves and three gastropods using bottom dredging and visual investigation in three different sites within the reservoir. The sampling sites were classified according to their distance from the dam, and all were close to agricultural lands. The samples were processed and frozen for qualitative toxicological analysis using mass spectrophotometry. Eight pesticides were identified, including four organochlorines (Aldrin, p,p'-DDE, Heptachlor epoxide, and Endrin) and organophosphates (Disulfoton, Malathion, Parathion- methyl, and Parathion-ethyl). All five studied species (Limnoperna fortunei, Corbicula fluminea, Melanoides tuberculata, Aylacostoma tenuilabris, and Pomacea aff. canaliculata) presented traces of pesticides in their bodies. Of the eight pesticides found in our analysis, six are illegal in Brazil, raising awareness about the continuous use of forbidden pesticides, and also the ecological risk in the Volta Grande Reservoir area. Our results suggest stricter control by environmental agencies regarding the use and commercialization of these illegal toxic compounds.
\end{abstract}

Keywords: bivalve, gastropoda, high contamination-risk, organic agrochemicals, pesticides.

\section{Moluscos de água doce como indicadores da presença de agrotóxicos no reservatório de Volta Grande, Brasil}

\section{RESUMO}

O Brasil tem vivenciado um aumento no uso de agroquímicos nos últimos anos, representando uma ameaça potencial aos ecossistemas. O reservatório de Volta Grande (Minas Gerais/São Paulo, Brasil) tem cerca de $87 \%$ de sua área cercada por sistemas agrícolas, e muitos 
compostos usados na agricultura acabam sendo transportados para corpos d'água próximos. Dado o potencial risco ecológico, nosso objetivo foi avaliar a presença de pesticidas utilizando moluscos de água doce como bioindicadores no reservatório de Volta Grande. Coletamos espécimes de dois bivalves e três gastrópodes usando dragas de fundo e sondagem visual, em três locais diferentes dentro do reservatório. Todos os pontos de amostragem foram classificados de acordo com suas distâncias da barragem, e todos estavam próximos a terras agrícolas. As amostras foram processadas e congeladas para análise toxicológica qualitativa por espectrofotometria de massa. Oito pesticidas foram identificados, incluindo quatro organoclorados (Aldrin, p,p'-DDE, Heptacloro epóxido e Endrin) e organofosforados (Disulfato, Malation, Paration-metil e Paration-etil). Todas as cinco espécies estudadas (Limnoperna fortunei, Corbicula fluminea, Melanoides tuberculata, Aylacostoma tenuilabris e Pomacea aff. canaliculata) apresentaram vestígios de pesticidas nos tecidos. Dos oito agrotóxicos encontrados em nossa análise, seis são ilegais no Brasil, reforçando a preocupação sobre o uso contínuo de agrotóxicos proibidos e também o risco ecológico na área do reservatório de Volta Grande. De acordo com os nossos resultados sugere-se um controle ambiental mais rigoroso por parte dos órgãos ambientais em relação ao uso e comercialização desses compostos tóxicos ilegais.

Palavras-chave: agroquímicos orgânicos, bivalve, gastropoda, pesticidas, risco de contaminação.

\section{INTRODUCTION}

Brazil has been experiencing intense growth in its agriculture sector for more than three decades. The country is considered one of the greatest agricultural exporters in South America and is projected to continually increase production for the next ten years (OECD/FAO, 2019). To sustain such growth in the agricultural sector, there has been also an increase in the production and use of agrochemicals, especially in the Southwestern region of Brazil (Bombardi, 2017). A great concern regarding the use of agrochemicals is the contamination of water bodies (Srivastav, 2020). A significant part of the agrochemical compounds used end up being transported by atmospheric processes, reaching aquatic environments (Bombardi, 2017). Man-made structures, such as dams and reservoirs, are constantly influenced by agricultural activities in the surrounding areas (Nilsson et al., 2005; Morais et al., 2014), and are subjected to inputted compounds carried through the watersheds (Frascareli et al., 2018). The disruptions of nutrient loads, sediment accumulation, water-flow, surrounded vegetation, and longitudinal gradients (Cantonati et al., 2020) caused by man-made reservoirs make them areas of high contamination-risk (Thornton et al., 1990).

Agrochemicals such as fertilizers (Khan et al., 2018) and pesticides (Starling et al., 2019) can be harmful to the environment, and especially to aquatic fauna. Previous studies have shown pesticide assimilation in invertebrates and consumers due to their chemical and physical properties, including hydrophobicity and linkage with total suspended solids (Rao and Ahmad, 2015). When invertebrates feed on nutrients contaminated with toxic compounds, these compounds accumulate in their bodies (bioaccumulation, Vidotti and Rollermber, 2004) and can be passed through the food web via trophic magnification, causing problems to consumers as well as to the predators that feed on invertebrates, including fish and humans (Gall et al., 2015; Rao and Ahmad, 2015).

Many mollusks are used as bioindicators of water quality, since they can greatly reflect diversity of species as well as environmental health and impacts (McGeoch, 1998; Oehlmann and Schulte-Oehlmann, 2003). Additionally, mollusks also present fairly long life cycles, the great majority are sessile or have low mobility range, and are relatively large, which facilitates sampling and understanding of ecological conditions in an area (Ligeiro et al., 2014). Such 
species are ideal tools to evaluate biomagnification and bioaccumulation of metal pollution in the water (Gupta and Singh, 2011), and can be indicators of anthropic alterations in the habitat (Asif et al., 2018). There are, for example, many suggestions in the literature of bivalves as bioindicators for organochlorine pesticide contamination in aquatic ecosystems (Larramendy and Soloneski, 2016; Shirapova and Morozov, 2020). Therefore, the sensitivity of mollusks to a wide range of environmental disturbances makes them good proxies for detecting environmental impacts.

Despite the contamination risk that mollusks are subject to in agriculturally-surrounded areas, little information is available about the presence of agrochemical pesticides in these water systems or their inhabitants. With the aim of filling this gap, the present study was performed to determine the presence of pesticides in the Volta Grande Reservoir's most abundant mollusks, to discuss the consequences of pesticide contaminants for the local aquatic fauna, and to point out concerns regarding the use of toxic compounds in the area.

\section{MATERIAL AND METHODS}

The study was conducted in three sites in the Volta Grande Reservoir, located in the Grande River Basin, a sub-basin of the upper Paraná River Basin (S 20 $2^{\prime} 5^{\prime \prime} \mathrm{W} 48^{\circ} 13^{\prime} 22^{\prime \prime}$; Figure 1). The hydroelectric power plant (HPP) of Volta Grande is located in the municipality of Conceição do Alagoas, between the states of Minas Gerais and São Paulo (Sanches et al., 2014). Site 1 is the closest to the dam, with crops and surrounding urban areas (S 20 $01^{\prime} 06^{\prime \prime} \mathrm{W}$ $\left.48^{\circ} 09^{\prime} 00^{\prime \prime}\right)$; Site 2 is the middle site, surrounded mainly by crops (S $\left.20^{\circ} 06^{\prime} 51^{\prime \prime} \mathrm{W} 48^{\circ} 02^{\prime} 16^{\prime \prime}\right)$; Site 3 is the most distant from the dam and is also mainly surrounded by crops ( $20^{\circ} 04^{\prime} 06^{\prime \prime} \mathrm{W}$ $\left.47^{\circ} 57^{\prime} 13^{\prime \prime}\right)$.

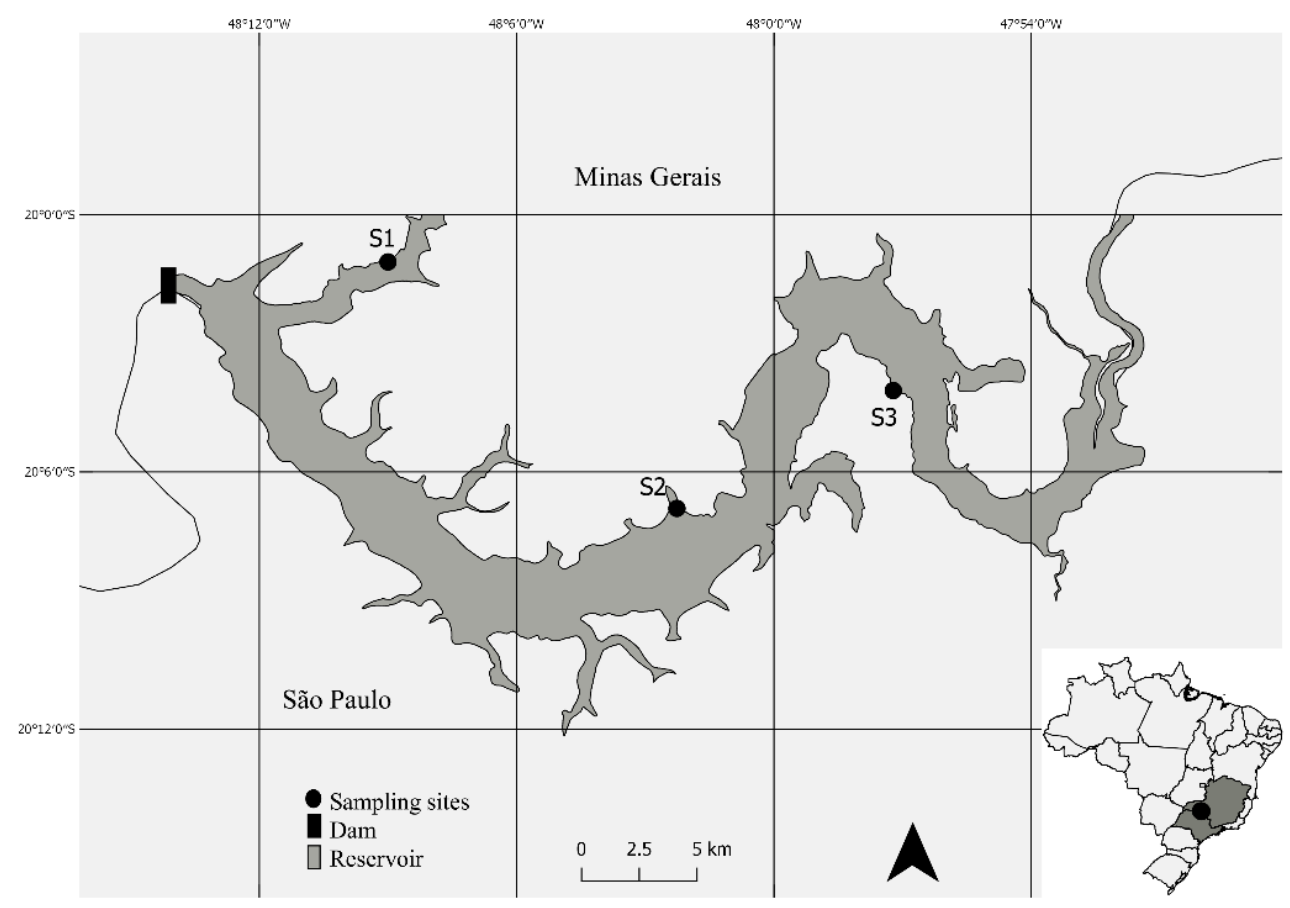

Figure 1. Three sampling sites (S1, S2, and S3) in the reservoir of the Volta Grande Hydroeletric Power Plant, Brazil (QGIS 2.18.22).

The Volta Grande Reservoir is located in São Paulo, the largest agricultural producing state of Brazil (IBGE, 2015). About $87 \%$ of the reservoir area is surrounded by agricultural lands (Macedo et al., 2014). The area is characterized by mean annual temperatures between $17^{\circ}$ and $26^{\circ} \mathrm{C}$ and annual accumulated precipitation of $1673 \mathrm{~mm}$ (INMET, 2010). The rainy season is 
between October and March and the dry season from April to September (data from local hydrometeorological reports). The soil around the reservoir is used for crops of soy and corn in the summer, beans, corn, or sorghum in the winter, and sugar cane year-round (Macedo et al., 2014). From the original vegetation cover (Rolla et al., 1992), only 6\% of forest patches remain; the rest is represented by other crops, open fields (4\%), cattle run, buildings, and roads (3\%) (Macedo et al., 2014).

We sampled three sites of the littoral zone in the Volta Grande Reservoir in January, April, and July 2016. We collected animals once each month, and we made an extra effort in January because the water was too turbid for visual collection. We selected the mollusks to be analyzed according to their abundance in the reservoir (Macedo et al., 2014). In order to collect mollusks, a Petersen-type bottom dredging and visual examination were employed. Via bottom dredging, three samples were obtained at each sampling site near the lakeshore, at depths ranging between 2 and $6 \mathrm{~m}$. In the visual examination, visual sediment surveys and hand catches were made at depths up to $1.5 \mathrm{~m}$, with a three-person sampling effort for 25 minutes at each site. Individuals found were sorted by species into $200 \mathrm{~mL}$ bottles. In total, 60 full bottles were collected (4 bottles/species for 5 species at each of the 3 sites). The captured specimens were identified (according to Simone, 2006 and Pereira et al., 2012), sorted by species, frozen and transported in sealed ice-boxes to be analyzed in the laboratory.

The frozen samples were submitted to qualitative toxicological analysis to determine the presence or absence of organic compounds. We put the macerate of viscera, muscle, and shell in the centrifuge to get the supernatant. Target organic analytes were isolated from the aqueous samples using solid-phase extraction (SPE) media, extracted by the methods EPA 8270-D (according to Lehotay and Schenck, 2000), and analyzed using mass spectrophotometry (EPA 8260C, 5021A, 525.3) in an ISO 17.025 certified laboratory. The compounds found, and further analyzed, were organochlorine (OC) and organophosphate (OP) pesticides, classified according to their chemical nature.

The pesticides were analyzed according to their bioaccumulation potential. According to Walters et al. (2016), the bioaccumulation potential is calculated using Trophic Magnification Factors (TMFs - "trophic level change in the log-concentration of a chemical"), which considers the relationship between compounds hydrophobicity values (Kow) and the metabolization time $(\mathrm{Km})$, to represent the compound's biomagnification potential in the food web. The octanol/water partition coefficient (hydrophobicity, Kow) corresponds to the solute affinity in a solution containing equal parts of octanol and water. This affinity property reflects the compound's reaction in a living organism's body with water and lipids (Silva and Ferreira, 2003). Meanwhile, the Km coefficient corresponds to the rate of metabolic biotransformation, or how long it takes for the compound to be metabolized by the organism (Walters et al., 2016). We obtained each compound's Kow and Km values from the literature (Kim et al., 2020), and applied the numerical relationship between Kow and $\mathrm{Km}$ in the figure model proposed by Walters et al. (2016, p. 4654) for TMF in freshwater ecosystems.

\section{RESULTS AND DISCUSSION}

The most abundant mollusks in the Volta Grande Reservoir selected for analysis were the nonnative species Limnoperna fortunei (Dunker, 1857), Corbicula fluminea (Muller, 1774), and Melanoides tuberculata (Muller, 1774); and the native species Aylacostoma tenuilabris (Reeve, 1860), and Pomacea aff. canaliculata (Lamarch, 1822). The toxicological analyses showed the presence of eight pesticides, four OC: Aldrin, p,p'-DDE (Dichlorodiphenyldichloroethylene, DDT [dichlorodiphenyl-trichloroethane] metabolite), Heptachlor epoxide, and Endrin; and four OP: Disulfoton, Malathion, Parathion-methyl, and Parathion-ethyl (Table 1). The less frequently found pesticides in the analyzed animals were: Heptachlor epoxide (only in $P$. aff. canaliculata, Sites 1

Rev. Ambient. Água vol. 16 n. 3, e2681 - Taubaté 2021 
and 3), and Parathion-methyl (only in C. fluminea, Site 1) (Table 1, Figure 2). The OPs Disulfoton, Parathion-ethyl, and Malathion were found in all five analyzed mollusks (Table 1). Pomacea aff. canaliculata, L. fortunei, and A. tenuilabris were found in all sampled sites; $C$. fluminea and $M$. tuberculata were not contaminated in Site 2 (Figure 3, Table 1). Each of the five species analyzed were contaminated with at least five contaminants. The species $C$. fluminea presented a higher number of contaminants (seven), followed by A. tenuilabris, and $P$. aff. canaliculata (six), while $L$. fortunei, and $M$. tuberculata presented five different contaminants. Site 1 was the most contaminated, with the presence of all pesticides across all samples.

Table 1. Presence of pesticides for each mollusk's species, $(P$. can $=P$. canaliculata; $C$. flu $=$ C. fluminea; L. for $=$ L. fortunei; A. ten $=A$. tenuilabris; $M$. tub $=$ M. tuberculata) in the Volta Grande reservoir for each sampling sites 1,2 , or 3 .

\begin{tabular}{cccccc}
\hline \multirow{2}{*}{ Pesticides } & \multicolumn{6}{c}{ Analyzed species } \\
\cline { 2 - 6 } & P. can & C. flu & L.for & A. ten & M. tub \\
\hline Aldrin & - & 1 & - & 1 & 1 \\
Endrin & 1,3 & 1,3 & $1,2,3$ & 2,3 & - \\
p,p'-DDE & 1,2 & 3 & 2,3 & $1,2,3$ & 1 \\
Heptachlor epoxide & 1,3 & - & - & - & - \\
Disulfoton & $1,2,3$ & 1,3 & 1,3 & 1,2 & 1,3 \\
Malathion & 2 & 3 & 1,3 & 1,2 & 1,3 \\
Parathion-ethyl & 1,2 & 1,3 & 1,3 & $1,2,3$ & 1,3 \\
Parathion- methyl & - & 1 & - & - & - \\
\hline
\end{tabular}

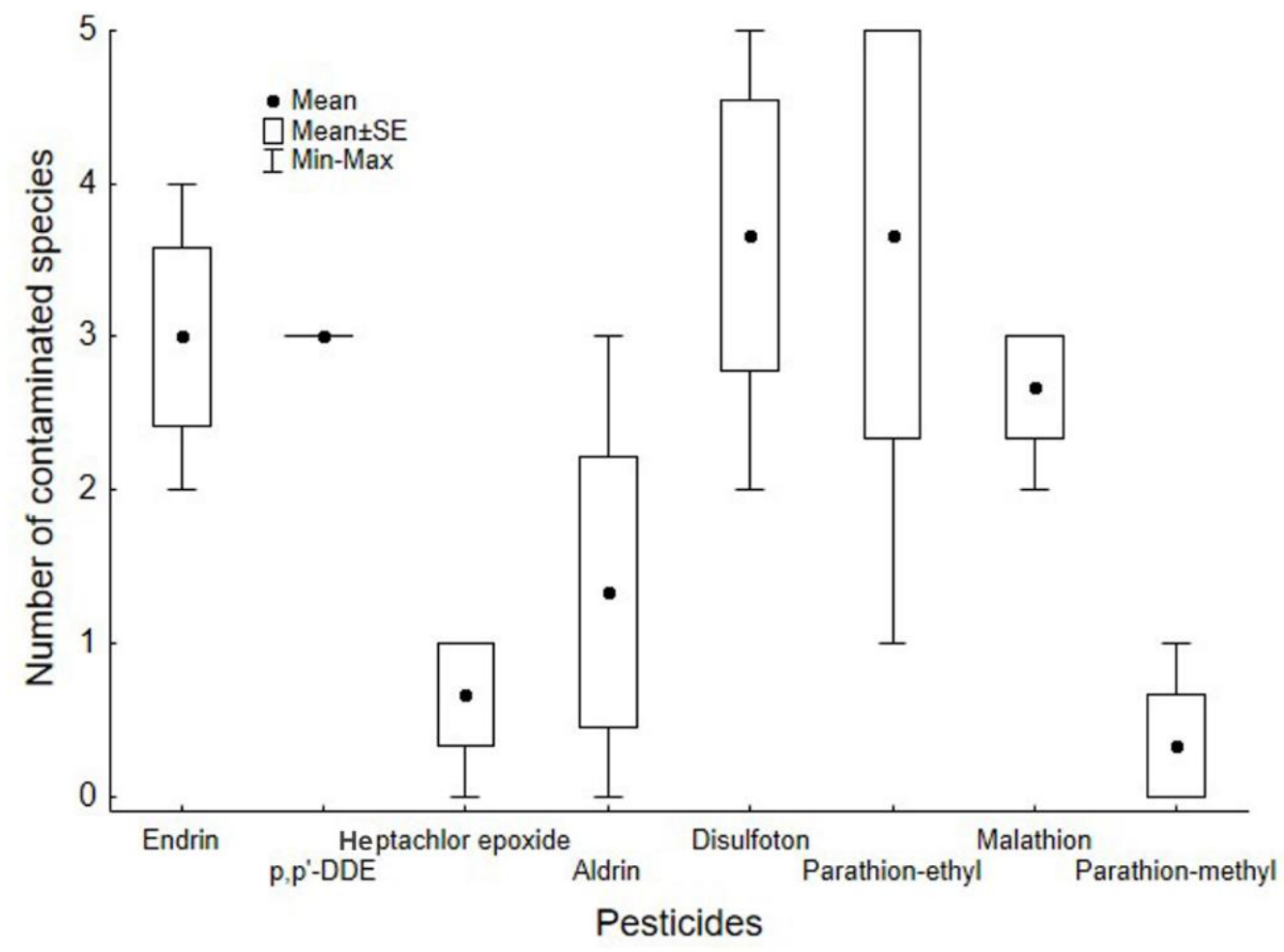

Figure 2. Mean $( \pm \mathrm{SE})$ number of contaminated species per pesticide. 


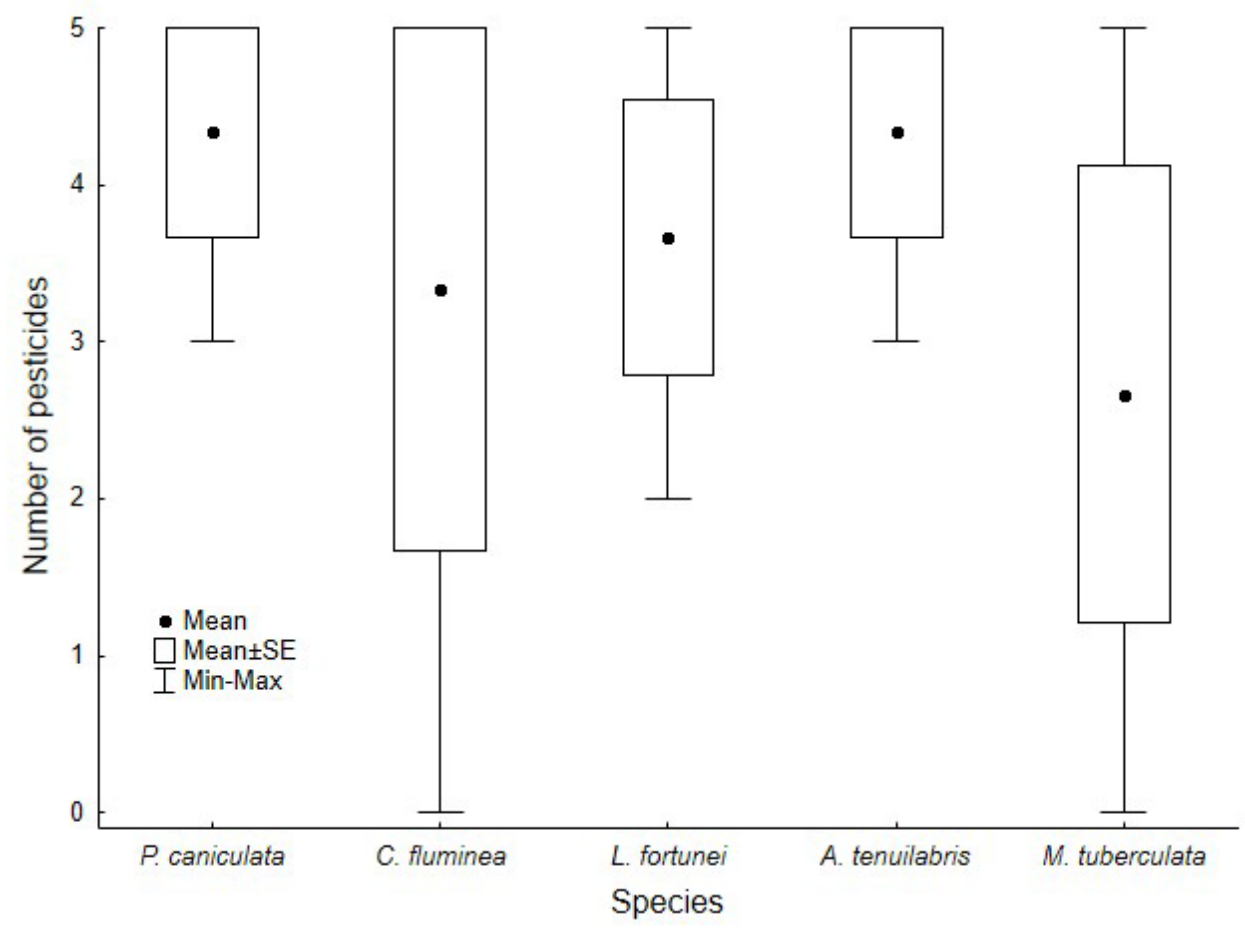

Figure 3. Mean $( \pm S E)$ number of pesticides found in each analyzed species.

The compounds found are well-known pesticides used in agricultural systems worldwide (Rao and Ahmad, 2015; Srivastav, 2020). The potential health hazards of these pesticides contributed to their prohibition in Brazil. From the pesticides we found contaminating the mollusk species in our study, Aldrin, DDT (the original form of p,p'-DDE), and Heptachlor epoxide were prohibited in Brazil in 1985 by the Ordinance $n^{\circ} 329$ (Ministério da Agricultura, Pecuária e Abastecimento) and Parathions in 1998, by the Ordinance $\mathrm{n}^{\circ} 11$ (Ministério da Saúde). Heptachlor epoxide, for example, was prohibited about 30 years ago, while both Parathions were prohibited about 19 years ago, and yet we found those compounds in most of the analyzed invertebrates across the sampling sites. Disulfoton and Malathion are not prohibited in Brazil, therefore their presence in the analyzed invertebrates implies a constant use in agricultural systems around the reservoir. Starling et al. (2019) reviewed the presence of pesticides in different watersheds across Brazil, and presented data on the widespread findings of prohibited pesticides in Brazilian waters. The authors' review corroborates our results that even forbidden compounds are still present in the environment, which can be potentially harmful to aquatic life. Furthermore, the presence of these pesticides in the animals can indicate continuous use of illegal compounds in agricultural areas (reinforced in Starling et al., 2019). The presence of DDT in all analyzed species is even more alarming due to its well-known toxicity (Blaylock, 2005) and extensive harmful effects discussed since the renewed publication of Rachel Carson's book, Silent Spring.

Based on the compounds' half-life (Mostafalou and Abdollahi, 2013), it is notable in our study that Heptachlor epoxide (2 years) and Parathion-ethyl (58 days) are still being used in Brazil even after their prohibition decades ago. Parathion-methyl has a very short half-life (112 days) and possibly does not stay long enough in the environment to contaminate most of the mollusks, explaining why we found only one species ( $P$. canaliculata) contaminated with Parathion-methyl in one site. This contamination may have happened very shortly before the animal collection. By contrast, Tong et al. (2018) indicated a tendency of bivalve mollusks to accumulate Heptachlor, Aldrin, or Endrin more than DDT, and it is important to reinforce that 
the contamination and accumulation can vary in different environmental conditions and species. The OPs Parathion-ethyl, Malathion, and Disulfoton were found in all studied mollusk species. Of those, Parathion-ethyl is the only one prohibited in Brazil, and should not be found in the environment.

To better visualize TMF results, we adapted the figure from Walters et al. (2016, p. 4654) and plotted the values found in our analysis for each compound (Figure 4). Our results showed that Aldrin presented a greater probability of being biomagnified when compared to the other OC, followed by p,p'-DDE, Endrin, and Heptachlor epoxide. For the OPs, Parathion-ethyl and Disulfoton presented low biomagnification probability (Figure 4). High TMF values, or high biomagnification potential, are represented by organic compounds that are moderately hydrophobic (Walters et al., 2016; log Kow 6-8) and are slowly metabolized by animals (Km $<0.01)$. The bioaccumulation potential shown by TMF values is important to indicate the possible effects of pesticides on the food web. The Aldrin found in our results (prohibited in Brazil), has a high probability of biomagnification and a relatively high half-life of 4-7 years (Walters et al., 2016). Malathion and Parathion-methyl (logKow 2.36 and 2.86, respectively; Hansch et al., 1996) were not represented in the graph since these two compounds have logKow values lower than 3.5 and therefore do not present a reliable relationship between Kow and Km that could demonstrate their biomagnification potential (Walters et al., 2016). According to the International Programme on Chemical Safety (IPCS) and the Food and Agriculture Organization of the United Nations (FAO), the low logKow of Parathion-methyl (and here extrapolated to Malathion), together with the compounds' short environmental persistence, indicate no potential to bioconcentrate.

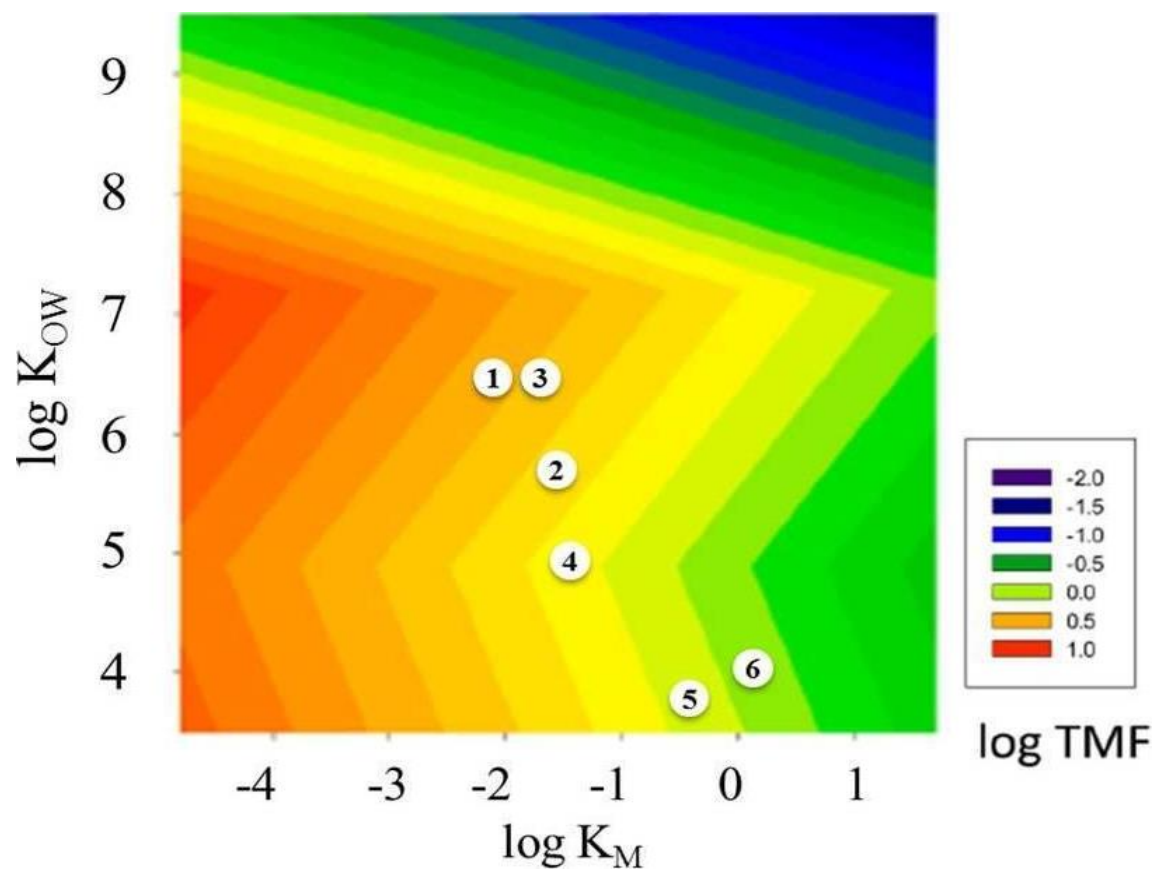

Figure 4. Relationship between metabolization time $(\log K m)$ and hydrophobicity (logKow) with log TMFs (presented as a colored gradient in $\mathrm{z}$ dimension). Each compound corresponds to a number: 1- Aldrin, 2Endrin, 3- p,p'-DDE, and 4- Heptachlor epoxide, 5- Parathion ethyl, 6Disulfoton. The colors indicate the accumulation probability, hot colors (red, orange, and yellow) indicate a high probability of accumulation (TMF $>0$ ) and cool colors (greens and blues) indicate a low probability of accumulation $(\mathrm{TMF}<1)$.

Source: Walters et al., 2016 (adapted).

We found Aldrin in three species of mollusks in Site 1 (C. fluminea, A. tenuilabris, $M$. 
tuberculata). Those same three species are important prey in the Volta Grande Reservoir (Rosa et al., 2021), meaning that this pesticide, with its high bioaccumulation potential and environmental persistence (Blaylock, 2005), may have been incorporated in the food chain. The one with the second-highest chance of bioaccumulation that we found, p,p'-DDE, has an even higher half-life (about 10 years) than Aldrin, and it is also prohibited in Brazil (Starling et al., 2019). Due to its known contamination harm and the high environmental persistence (Blaylock, 2005), it is alarming that we identified p,p'-DDE in all five mollusk species and all three sampling sites. Endrin presents moderate biomagnification potential and a very wide half-life range (1-12 years). This compound is not prohibited in Brazil, but because it is relatively persistent in the environment (Blaylock, 2005) and the food chain, it can be potentially harmful for the four contaminated mollusk species and the reservoir in general.

The presence of eight pesticides in the analyzed mollusks suggests that the agricultural activity in the surrounding areas of the Volta Grande Reservoir may be impacting the local fauna (as seen in Rao and Ahmad, 2015; Baqar et al., 2018). Some of the pesticides found in our study were also reported in the Parana River Basin's (which includes the Rio Grande) water and sediment samples, including Parathions, Heptachlor, and Aldrin (Lenardon et al., 1984). A more recent study in the Furnas Reservoir (in the Rio Grande sub-basin), showed the presence of OC in the water, gills, and liver of two fish species (Psalidodon fasciatus and Pimelodus maculatus) (Paulino et al., 2014). The harmful and even deadly effects of Endrin in fish and birds that feed on Pomacea have been already demonstrated (Vermeer et al., 1974). Vertebrates such as fish and birds may have been contaminated in the Volta Grande Reservoir since they rely on L. fortunei and $P$. aff. canaliculata as important items in their diets (Halwart, 1994; Sylvester et al., 2007). The fish Leporinus friderici, with commercial and environmental importance in the region, may also be contaminated, since it intensely feeds on L. fortunei (Rosa et al., 2021). Coat et al. (2011) detected a strong and widespread food-web contamination by OC in freshwater ecosystems and the pesticides strongly accumulated by mollusks and shrimps can be affecting higher level animals such as fishes. Organochlorines present higher bioaccumulation potential and environmental persistence than other pesticides (Baird and Cann, 2011). Even though the OC found in our work presented reduced or non-determined bioaccumulation potential, their presence in all species and sites raises an alert regarding the control of prohibited pesticides and the need for further studies on the potential damages caused by these compounds in local environments. However, to assess the trophic contamination risk and food web contamination, more detailed studies are encouraged, including the predators' diets and toxicological analysis to complement our results.

Besides the legal implications of pesticide use and their effects on the food chain, these compounds may also be directly harmful to the animals in the reservoir. As reviewed by Nowell et al. (1999), the effects of pesticide on aquatic organisms, specifically mollusks, may include development, reproduction, and behavior changes, endocrine disruption, decreased reproductive success, and defeminization and masculinization of females. Since we found pesticides contaminating all five analyzed mollusks species, as well as some species contaminated with multiple pesticides, there is an increasing concern regarding the reservoir wildlife health and the ecological implications of populations disruptions caused by contamination.

\section{CONCLUSIONS}

From our results, we suggest that stronger and continuous control is necessary for the Volta Grande Reservoir area to avoid the selling and use of prohibited pesticides. The presence of some pesticides (Heptachlor epoxide, Parathion-methyl, and Parathion-ethyl) in the analyzed mollusks implies that they are still being used even after decades of prohibition. With the

Rev. Ambient. Água vol. 16 n. 3, e2681 - Taubaté 2021 
agriculture sector continuously expanding, pesticide use tends to rise as well, and therefore the control should also arise to avoid environmental damages and trophic contamination.

More studies are necessary for the Grande and Paraná River Basins, as well as other similar locations surrounded by agricultural systems, to address how the pesticides are impacting the food web and to support management actions to avoid further contamination. The present work is the first to provide information about pesticide contamination in mollusks of the Grande River Basin. This work is an advisory about the present scenario of pesticide contamination in the region, and raises questions about the environmental health in areas surrounded by agriculture. Considering all the problems pointed out by our work regarding pesticide contamination in the Volta Grande Reservoir area, we emphasize the need for further work to show more details of contamination in the whole food web, the need for a more controlled use of pesticides, and the importance of bringing more awareness and information to local communities regarding the laws and risks of agrochemical use.

\section{ACKNOWLEDGEMENTS}

We would like to thank Márcia, Paulo and the UFLA Fish Ecology lab group for the support in the field. Jessica Schulte for the English review. André Maciel for textual review. The funding of FAPEMIG (Fundação de Amparo à Pesquisa do Estado de Minas Gerais), CAPES (Coordenação de Aperfeiçoamento de Pessoal de Nível Superior), FUNDECC (Fundação de Desenvolvimento Científico e Cultural), and CEMIG (Companhia Energética de Minas Gerais).

\section{REFERENCES}

ASIF, N.; MALIK, M.; CHAUDHRY, F. N. A review of environmental pollution bioindicators. Pollution, v. 4, n. 1, p. 111-118, 2018. https://dx.doi/10.22059/poll.2017.237440.296

BAIRD, C.; CANN, M. Pesticidas. In: BAIRD, C.; CANN, M. Química ambiental. Porto Alegre: Bookman, 2011. p. 471-489.

BAQAR, M.; SADEF, Y.; AHMAD, S.; MAHMOOD, A.; LI, J.; ZHANG, G. Organochlorine contaminants in freshwater mussels; occurrence, bioaccumulation pattern, spatiotemporal distribution and human health risk assessment from the tributaries of River Ravi, Pakistan. Human and Ecological Risk Assessment: An International Journal, v. 24, n. 5, p. 1268-1290, 2018. https://dx.doi/10.1080/10807039.2017.1411780

BLAYLOCK, B. L. DDT (Dichlorodiphenyltrichloroethane). Encyclopedia of Toxicology, v. 2, p. 725-727, 2005. https://dx.doi/10.1016/B0-12-369400-0/00291-X

BOMBARDI, L. M. Geografia do uso de agrotóxicos no Brasil e conexões com a União Europeia. São Paulo: FFLCH - USP, 2017. E-book (296 p.).

CANTONATI, M.; POIKANE, S.; PRINGLE, C. M.; et al. Characteristics, main impacts, and stewardship of natural and artificial freshwater environments: Consequences for biodiversity conservation. Water, v. 12, n. 1, p. 260, 2020. https://dx.doi/10.3390/w12010260

COAT, S.; MONTI, D.; LEGENDRE, P.; BOUCHON, C.; MASSAT, F.; LEPOINT, G. Organochlorine pollution in tropical rivers (Guadeloupe): role of ecological factors in food web bioaccumulation. Environmental Pollution, v. 159, n. 6, p. 1692-1701, 2011. https://dx.doi/10.1016/j.envpol.2011.02.036 
FRASCARELI, D.; CARDOSO-SILVA, S.; MIZAEL, J. O. S. et al. Spatial distribution, bioavailability, and toxicity of metals in surface sediments of tropical reservoirs, Brazil. Environmental monitoring and assessment, v. 190, n. 4, p. 190-199, 2018. https://dx.doi/10.1007/s10661-018-6515-8

GALL, J.E.; BOYD, R. S.; RAJAKARUNA, N. Transfer of heavy metals through terrestrial food webs: a review. Environmental monitoring and assessment, v. 187, n. 4, p. 201, 2015. https://dx.doi/10.1007/s10661-015-4436-3

GUPTA, S. K.; SINGH, J. Evaluation of mollusc as a sensitive indicator of heavy metal pollution in an aquatic system: a review. The II OAB Journal, v. 2, n. 1, p. 49-57, 2011.

HALWART, M. The golden apple snail Pomacea canaliculata in Asian rice farming systems: present impact and future threat. International Journal of Pest Management, v. 40, n. 2, p. 199-206, 1994. https://dx.doi/10.1080/09670879409371882

HANSCH, C.; LEO, A.; HOEKMAN, D. Exploring QSAR - Hydrophobic, Electronic, and Steric Constants. Journal of American Chemical Society, n.118, p. 1189-1191, 1996. https://dx.doi/10.1021/ja965433

IBGE. Produção Agrícola Municipal (PAM). 2015. Available in: https://www.ibge.gov.br/estatisticas/economicas/agricultura-e-pecuaria/9117-producaoagricola-municipal-culturas-temporarias-e-permanentes.html?edicao $=9118 \& \mathrm{t}=$ sobre . Access in: August 2017.

INMET. Normais climatológicas do Brasil. 2010. Available in: https://portal.inmet.gov.br/normais. Access in: February 2020.

KHAN, M. N.; MOBIN, M.; ABBAS, Z. K.; ALAMRI, S. A. Fertilizers and their contaminants in soils, surface and groundwater. Encyclopedia of the Anthropocene, v. 5, p. 225-240, 2018. https://dx.doi/10.1016/B978-0-12-809665-9.09888-8

KIM, S.; THIESSEN, P.A.; BOLTON, E.E.; et al. PubChem Substance and Compound databases. Nucleic Acids Research, v. 44, n. D1, p. D1202-1213, 2020. https://dx.doi/10.1093/nar/gkv951

LARRAMENDY, M.; SOLONESKI, S. Invertebrates: Experimental Models in Toxicity Screening. 1. ed. Rijeka: InTech, 2016. 117.

LEHOTAY, S. J.; SCHENCK, F. J. Multi-residue methods: extraction. In: WILSON, I. D. et al. (ed.) Encyclopedia of separation Science. Cambridge: Academic Press, 2000. p. 3409-3415.

LENARDON, A. M.; HEVIA, M. I. M.; FUSE, J. A.; NOCHETTO, C. B.; DEPETRIS, P. J. Organochlorine and organophosphorus pesticides in the Parana River (Argentina). Science of the total environment, v. 34, n. 3, p. 289-297, 1984. https://dx.doi/10.1016/0048-9697(84)90070-6

LIGEIRO, R.; FERREIRA, W.; CASTRO, D.; FIRMIANO, K. R.; SILVA, D.; CALLISTO, M. Macroinvertebrados bentônicos em riachos de cabeceira: múltiplas abordagens de estudos ecológicos em bacias hidrográficas. In: CALLISTO, M.; ALVES, C. B. M.; LOPES, J. M.; CASTRO, M. A. (org.). Condições ecológicas em bacias hidrográficas de empreendimentos hidrelétricos. Belo Horizonte: Companhia Energética de Minas Gerais, 2014. cap. 6, p. 127-160. 
MACEDO, D. R.; POMEPU, P. S.; MORAIS, L.; CASTRO, M.; ALVES, C. B. M.; FRANÇA, J. S.; SANCHES, B.; UCHÔA, J.; CALLISTO, M. Uso e ocupação do solo, sorteio de sítios amostrais, reconhecimento em campo e realização de amostragens. In: Condições ecológicas em bacias hidrográficas de empreendimentos hidrelétricos. Belo Horizonte: Companhia Energética de Minas Gerais, 2014. p. 47-68.

MCGEOCH, M. A. The selection, testing and application of terrestrial insects as bioindicators. Biological reviews, v. 73, n. 2, p. 181-201, 1998. https://dx.doi/10.1111/j.1469185X.1997.tb00029.x

MORAIS, L; FARIAS R. L.; MARTINS, I.; BARBOSA, J. E. L.; MOLOZZI, J.; ANACLÉTO, M. J.; CALLISTO, M. Bioindicadores bentônicos de qualidade ambiental em reservatórios da CEMIG. In: Condições ecológicas em bacias hidrográficas de empreendimentos hidrelétricos. Belo Horizonte: Companhia Energética de Minas Gerais, 2014. p. 161-184.

MOSTAFALOU, S.; ABDOLLAHI, M. Pesticides and human chronic diseases: evidence, mechanisms, and perspectives. Toxicology and applied pharmacology, v. 268, n. 2, p. 157-177, 2013. https://dx.doi/10.1016/j.taap.2013.01.025

NILSSON, C.; REIDY, C. A.; DEYNESIUS, M.; REVENGA, C. Fragmentation and flow regulation of the world's large river systems. Science, v. 308, n. 5720, p. 405-408, 2005. https://dx.doi/10.1126/science.1107887

NOWELL, L. H.; CAPEL, P. D.; DILEANIS, P. D. Analysis of key topics-Environmental significance. In: NOWELL, L. H.; CAPEL, P. D.; DILEANIS, P. D. Pesticides in stream sediment and aquatic biota: distribution, trends, and governing factors. 1. ed. Boca Raton, Florida: CRC Press, 1999. 971 p.

OECD/FAO. Latin American Agriculture: Prospects and Challenges. In: OECD/FAO. Agricultural Outlook 2019-2028. Rome, 2019. p. 70-124.

OEHLMANN, J.; SCHULTE-OEHLMANN, U. Molluscs as bioindicators. Trace Metals and other Contaminants in the Environment, v. 6, p. 577-635, 2003. https://dx.doi/10.1016/S0927-5215(03)80147-9

PAULINO, M. G.; BENZE, T. P.; SADAUSKAS-HENRIQUE, H.; SAKURAGUI, M. M.; FERNANDES, J. B.; FERNANDES, M. N. The impact of organochlorines and metals on wild fish living in a tropical hydroelectric reservoir: bioaccumulation and histopathological biomarkers. Science of the Total Environment, v. 497, p. 293-306, 2014. https://dx.doi/10.1016/j.scitotenv.2014.07.122

PEREIRA, D.; MANSUR, M. C. D.; PIMPÃO, D. M. Identificação e diferenciação dos bivalves límnicos invasores dos demais bivalves nativos do Brasil. In: MANSUR, M. C. D.; SANTOS, C. P.; PEREIRA, D.; PAZ, I. C. P.; ZURITA, M. L. L.; RODRIGUEZ, M. T. R.; NEHRKE, M. V.; BERGONCI, P. E. A. (org.) Moluscos límnicos invasores no Brasil: biologia, prevenção e controle. Porto Alegre: Redes, 2012. cap. 5, p. 75-94.

RAO, M. R. J.; AHMAD, K. Occurrence of Organochlorine and Organophosphorus Pesticides in M. scabra and M. tuberculata Species in Tighra Reservoir, Gwalior, India. Environmental Claims Journal, v. 30, n. 3, p. 216-227, 2015. https://dx.doi/10.1080/10406026.2018.1467089 
ROLLA, M. E.; DEBÉS, M. B. G. S; FRANÇA, R. C.; FERREIRA, E. M. V. M. Inventário limnológico do rio Grande na área de influência da futura usina hidrelétrica (UHE) de Igarapava. Acta Limnologica Brasiliensia, v. 4, p. 139-162, 1992.

ROSA, D.M.; SENE, A.M.; MOREIRA, M.Z.; POMPEU, P.S. Non-native prey species supporting fish assemblage biomass in a Neotropical reservoir. Biol Invasions, 2021. https://doi.org/10.1007/s10530-021-02510-X

SANCHES, B. O.; BECKER, B.; GOMES, P. L. A.; SANTOS, G. B. A ictiofauna de quatro reservatórios da CEMIG: caracterização das comunidades. In: Condições ecológicas em bacias hidrográficas de empreendimentos hidrelétricos. Belo Horizonte: Companhia Energética de Minas Gerais, 2014. p. 185-214.

SHIRAPOVA, G.; MOROZOV, S. Organochlorine pesticides in Baikal bivalve mollusc Colletopterum ponderosum sedakovi. IOP Conference Series: Materials Science and Engineering, v. 962, n. 4, p. 042042, 2020. https://dx.doi/10.1088/1757$899 X / 962 / 4 / 042042$

SILVA, L.; FERREIRA, M. Estudo do coeficiente de partição octanal-água de bifenilas policloradas (PCBs) utilizando parâmetros topológicos. Química Nova, v. 26, n. 3, p. 312-318, 2003. https://dx.doi/10.1590/s0100-404220

SIMONE, L. R. L.; Land and freshwater molluscs of Brazil. 2. ed. São Paulo: EGB; Fapesp, 2006. 390 p.

SRIVASTAV, A. L. Chemical fertilizers and pesticides: Role in groundwater contamination. Agrochemicals Detection, Treatment and Remediation. Oxônia: ButterworthHeinemann, 2020. p. 143-159. https://dx.doi/10.1016/B978-0-08-103017-2.00006-4

STARLING, M. C. V.; AMORIM, C. C.; LEÃO, M. M. D. Occurrence, control and fate of contaminants of emerging concern in environmental compartments in Brazil. Journal of $\begin{array}{llllll}\text { hazardous materials, } & \text { v. } & 372, & \text { p. } & 17-36,\end{array}$ https://dx.doi/10.1016/j.jhazmat.2018.04.043

SYLVESTER, F.; BOLTOVSKOY, D.; CATALDO, D. H. Fast response of freshwater consumers to a new trophic resource: predation on the recently introduced Asian bivalve Limnoperna fortunei in the lower Paraná River, South America. Austral Ecology, v. 32, n. 4, p. 403-415, 2007. https://dx.doi/10.1111/j.1442-9993

THORNTON, K. W.; KIMMEL, B. L.; PAYNE, F. E. Reservoir Limnology: Ecological Perspectives. New York: John Wiley and Sons, 1990. 256 p.

TONG, N. X.; THI, T.; HUONG, T.; THUY, D. T.; HUONG, M.; TRONG, D.; LUC, H. C.; LOAN, P. T.; THI, L.; QUYNH, P. Bioaccumulation of organochlorine pesticides (OCPs) in molluscs and fish at the Sai Gon - Ding Nai estuary. Journal of Viernamese Environment, v. 9, n. 5, p. 248-254, 2018. https://dx.doi/10.13141/jve.vol9.no5.pp248254

VERMEER, K.; RISEBROUGH, R. W.; SPAANS, A. L.; REYNOLDS, L. M. Pesticide effects on fishes and birds in rice fields of Surinam, South America. Environmental Pollution, v. 7, n. 3, p. 217-236, 1974. 
VIDOTTI, E. C.; ROLLERMBERG, M. D. C. E. Algas: da economia nos ambientes aquáticos à biorremediação e à química analítica. Química Nova, v. 27, p. 139-145, 2004. https://dx.doi/10.1590/S0100-4042

WALTERS, D. M.; JARDINE, T. D.; CADE, B. S.; KIDD, K. A.; MUIR, D. C. G.; LEIPZIGSCOTT, P. Trophic magnification of organic chemicals: A global synthesis. Environmental Science \& Technology, v. 50, n. 9, p. 4650-4658, 2016. https://dx.doi/10.1021/acs.est.6b00201 